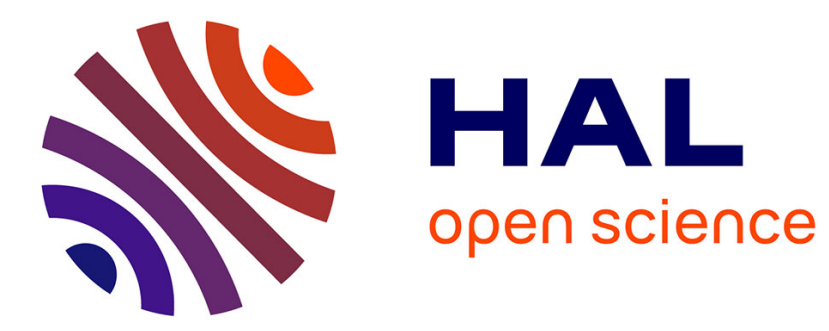

\title{
Abstentionist voting - between disengagement and protestation in neglected areas: a spatial analysis of the Paris metropolis
}

\author{
Sébastien Bourdin, Jiwan Tai
}

\section{- To cite this version:}

Sébastien Bourdin, Jiwan Tai. Abstentionist voting - between disengagement and protestation in neglected areas: a spatial analysis of the Paris metropolis. International Regional Science Review, 2021, 10.1177/01600176211034131 . hal-03271515

\section{HAL Id: hal-03271515 \\ https://hal.science/hal-03271515}

Submitted on 25 Jun 2021

HAL is a multi-disciplinary open access archive for the deposit and dissemination of scientific research documents, whether they are published or not. The documents may come from teaching and research institutions in France or abroad, or from public or private research centers.
L'archive ouverte pluridisciplinaire HAL, est destinée au dépôt et à la diffusion de documents scientifiques de niveau recherche, publiés ou non, émanant des établissements d'enseignement et de recherche français ou étrangers, des laboratoires publics ou privés. 


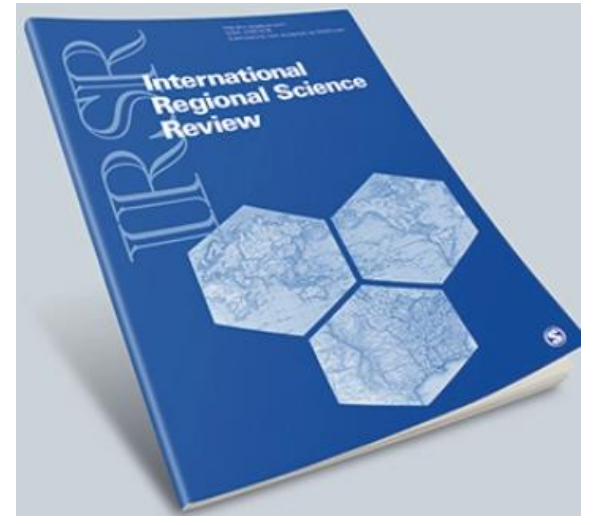

\title{
Abstentionist voting - between disengagement and protestation in neglected areas: a spatial analysis of the Paris metropolis
}

\author{
SEBASTIEN BOURDIN, EM NORMANDIE MÉTIS LAB* \\ JIWAN TAI, EM NORMANDIE MÉTIS LAB
}

\section{* sbourdin@em-normandie.fr}

Abstract: This article analyzes electoral behaviors related to voting abstention in the Metropolis of Paris. We highlight the interest of a contextual approach to examine non-voting behaviors. Using socioeconomic and demographic data at the level of municipalities, we construct a spatial model to explain the reasons for abstention. Our results support the idea that abstentionism expresses a disengagement behavior as well as a protestation behavior. People disengage from politics because they believe that politicians (no matter which party is in power) will not be able to change their situation. This hypothesis applies to non-voters peripheral to political life. We also show that these people tend to live in socioeconomically marginalized areas. The protest attitude is found especially in "left-behind" areas that have experienced a significant decline in the supply of public services and local shops. Bridging the divide in these neglected areas is essential to avoid further marginalization and growing protest.

Keywords: abstentionism, electoral behavior, discontent, protest, disengagement, discontent, spatial analysis

JEL: D72, R10, R50 


\section{Paper accepted in International Regional Science Review}

\section{Introduction}

Over the last ten years, political science and geography in France have tended to converge in terms of analysis of electoral behavior. The detailed utilization of data has revived several academic debates (gradient of urbanity and political behavior; behavior deemed contentious in peri-urban areas; abstention, urban neighborhoods in difficulty, etc.). Several geographers have highlighted the value of contextual analyses (Agnew, 1996) and the contributions of fine-scale analysis when studying urban electoral dynamics (Cox, 1968). The study of electoral behavior on a fine geographic scale has also been widely developed among politicians, particularly following the work of Stanyer (1975) and Busteed (1975). Whether it be voter behavior within a city (Sonenshein and Drayse, 2006; Weaver, 2014; Charney and Malkinson, 2015; Ubarevičienė et al., 2015) or electoral dynamics between cities, periurban areas and the countryside (Walks, 2005; De Maesschalck, 2011; Roy et al., 2015; Scala and Johnson, 2017) or between regions (Dijkstra et al., 2020), the number of studies dealing with the geographical context of voting has continued to grow, often from a multidisciplinary perspective involving geographers, sociologists and politicians. Recently, we have seen the emergence of work in regional science that has pushed the contextual analyses pursued in electoral geography even further by highlighting how territorial characteristics and their evolving situation can affect voting (RodríguezPose, 2018 and 2020; Hendrickson et al., 2018; Dijkstra et al., 2019; McCann, 2020).

These analyses in regional science mainly focus on the anti-establishment/anti-system vote, but, to our knowledge, have not previously investigated the abstentionist vote, even though the latter can be considered as disengagement or protest behavior, as the literature on electoral sociology suggests. While several studies have examined the reasons for abstention in the sociology of voting and political science (Portos et al., 2020), only a few have analyzed the extent of participation in elections from a spatial perspective. It is thus in this context that our study is situated.

In studies of the protest vote, two types of approach can be distinguished to explain electoral behavior: an approach centered on the individual (i.e., Buton et al., 2012; Ford and Goodwin, 2014) and an approach centered on the territorial context (Rivière, 2008; Guilluy, 2019; Rodríguez-Pose, 2018, 2020). Following recent work in regional science, our focus is on the second approach and examines places 


\section{Paper accepted in International Regional Science Review}

considered as "left behind" (remote and/or economically disadvantaged areas). Abstentionist voting can be considered in two ways. The first is characterized by non-voters who are peripheral to political life (e.g., young people, those with low levels of education or the unemployed, and those whose parties have failed to reach them). Political scientists explain this through the fact that voters no longer bother to go to the polls because they have lost confidence in politics or lack interest in it (Kostelka, 2017; Heath, 2018). For these people, their abstention can be considered either as electoral behavior of disengagement/disenchantment or as contestation (Gianturco et al., 2015). The second approach emphasizes the active choice not to vote: in this case, abstentionism is viewed as an opinion expressed by individuals at the center of political life who aim to send an explicit message of protest against parties and the political system (Legnante and Segatti, 2009; Kselman and Niou, 2011; Superti, 2014). In both cases, recent publications in regional science have highlighted that this protest vote can be explained by territorial characteristics that influence voter behaviors. More precisely, voters tend to express a higher proportion of protest votes in areas marked by decline (Rodríguez-Pose, 2018 and 2020; Lee et al., 2018; Dijkstra et al., 2020; van Leeuwen et al., 2020).

Our paper contributes to the literature on electoral geography and complements other recent contributions in regional science since the focus is not on the geography of populist voting but rather on abstentionist voting. This is important as discontent can be expressed at the ballot box in different ways. This paper, therefore, looks at whether the abstentionist vote is a vote of disenchantment and/or a protest vote. Two types of explanation can be advanced. First, in areas where there is a concentration of politically and/or sociologically marginalized populations, there is a higher abstention rate. This hypothesis refers to non-voters who are peripheral to political life (due to high unemployment, a large share of immigrants, etc.). They have a disenchantment attitude as they feel abandoned by politicians and public policies and believe that voting will not change their lives (Hughes and Guerrero, 2009; Lahtinen et al., 2017). Second, territories with sustained economic hardship and marginalization are more likely to experience high levels of abstention. This hypothesis refers to non-voters living in peripheral/shrinking territories who tend to have a protestation attitude (Rodríguez-Pose, 2018; Gordon, 


\section{Paper accepted in International Regional Science Review}

2018; Dijkstra et al., 2020) and, by abstaining, aim to show that they are protesting against the politicians and their political and ideological offerings (Kselman and Niou, 2011).

We decided to conduct our study in a large global metropolis as this is where inequalities are particularly exacerbated (Duranton et al., 2015; Sampson, 2019; Nijman and Wei, 2020). From this perspective, work on electoral geography finds a fertile field of study in the analyses of metropolitan areas (Cox et al., 2007). We focused on the Paris Metropolis since it constitutes an archetype of urban segregation processes (Le Roux et al., 2017; McAvay and Verdugo, 2021). Paris is undoubtedly one of the most emblematic French cities, where electoral geography has changed little and where we can observe spatial patterns of socio-economic disparities linked to a variety of electoral behaviors (Rivière, 2012). The extremely strong stability of the east-west divide, observable since the 1950s, no doubt partially explains this tropism. Despite changes in the electoral context, the boundaries, and the scale of analysis, a comparison of the maps obtained by Klatzmann (1957), Ranger (1977) and Rivière (2012) reveals sharp division between the up-market neighborhoods in the west, with strong right-leaning majorities, and the more grassroots neighborhoods in the east, where left-wing parties are far more present. At the same time, the relative weakness of the extreme right-wing party is also a key characteristic of the French capital, with the extremist vote being somewhat localized in peri-urban areas.

Presidential voting patterns are the result of myriad demographic, economic, geographic and social phenomena. Since the variables for which information is available are geo-localized, they are characterized by spatial dependencies that are all the stronger the closer they are in terms of distance. Taking this factor into account, it thus becomes possible to consider spatial interactions and externalities in our analysis of the observed phenomena. Consequently, we use regression models that incorporate the spatial dimension to represent the combined influence of these factors.

The paper is structured as follows: First, we go back to the literature to identify the reasons for electoral demobilization. We then present the methodology and the data used. Finally, we present the results of our analysis before moving on to the conclusion. 


\section{Reasons for electoral demobilization}

Since the first European elections were held in 1979, voter turnout has fallen by more than 20 points, in line with the low level of interest in these elections (62\% of French people said they had little or no interest in them, according to an Ipsos survey conducted in May 2014), and disaffection with EU institutions recorded by the Eurobarometer has been particularly pronounced since the 2008 crisis (-17 points of confidence in the same Ipsos survey). While the presidential elections see the biggest turnout, they have also experienced an increase in abstention (Table 1).

Table 1. Evolution of the abstentionist vote in the French presidential elections ${ }^{l}$

\begin{tabular}{|c|c|c|c|c|c|c|c|}
\cline { 2 - 8 } \multicolumn{1}{c|}{} & 1981 & 1988 & 1995 & 2002 & 2007 & 2012 & 2017 \\
\hline 1st round & $18.9 \%$ & $18.6 \%$ & $21.6 \%$ & $28.4 \%$ & $16.23 \%$ & $20.52 \%$ & $22.23 \%$ \\
\hline 2nd round & $14.1 \%$ & $15.9 \%$ & $20.3 \%$ & $20.29 \%$ & $16.03 \%$ & $19.65 \%$ & $25.44 \%$ \\
\hline
\end{tabular}

Figure 1. Voter turnout in presidential elections (\% of those surveyed $\left.{ }^{2}\right)$

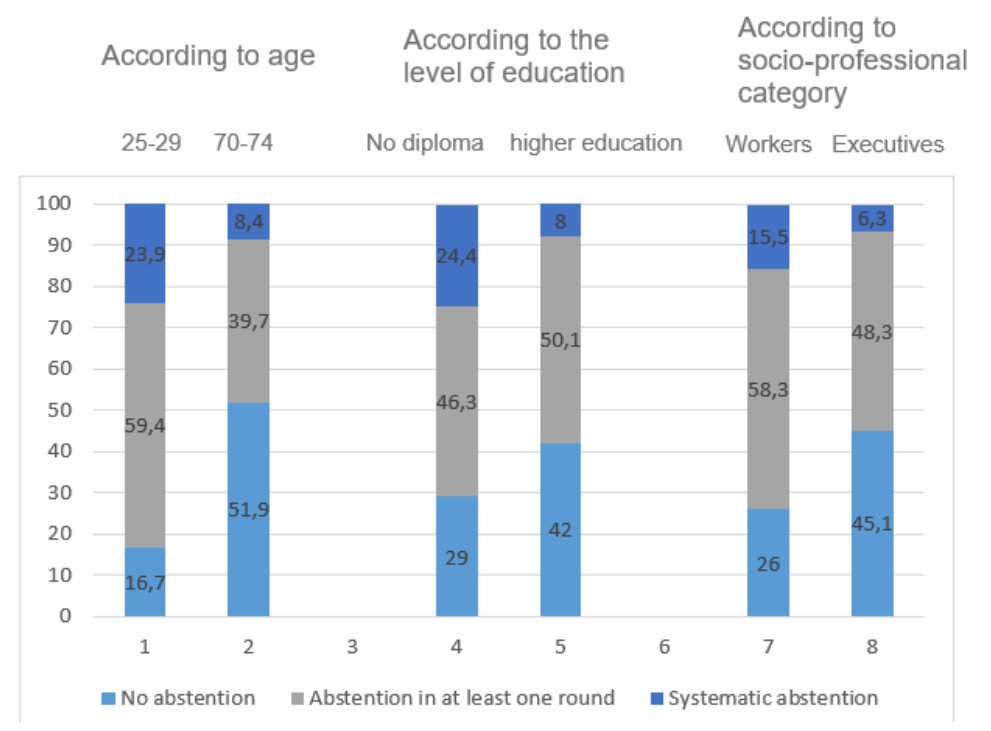

Regarding abstention, we can note some stylized facts about the behavior of voters during the 2017 presidential election. Abstention in the last election broke all records, but the increase in abstention only affected part of the population. There was no democratization of abstention: workers and executives did not vote in the same way. People who tended to abstain were, above all, the working classes and young

\footnotetext{
${ }^{1}$ France uses a two-round electoral system"

2 40,000 people were surveyed (INSEE)
} 


\section{Paper accepted in International Regional Science Review}

people. Level of education was the most discriminating criterion. School indeed provides the keys to understanding politics, and the higher the level of education, the more one feels entitled to speak out (Braconnier and Dormagen, 2007). Age has always been an important determinant of voter turnout. As Esser and De Vreese (2007) showed in the United States context, the more professionally integrated people are, the more they are likely to talk about politics. People now join the labor market later and later, which explains why these gaps have grown larger over the years. Professional integration is decisive in electoral participation, but we can also observe differences between socio-professional categories. Some individuals accumulate factors leading to abstention, in other words, they are less qualified, have unstable jobs and little wealth (Anderson and Beramendi, 2012; Leighley and Nagler, 2013; Heath, 2018). The disavowal of politics is therefore increasingly marked socially, and voter turnout reveals deep inequalities.

For the past 30 years or so, voter turnout has been observed to be in decline in most Western countries (Kostelka, 2017). The main explanatory factors mentioned in the literature on sociological models of voting are: (1) the destabilization and disorganization of the working class, (2) the loss of political influence of religious institutions, and (3) the new, less participatory civic norms among the younger generations. However, these models are becoming less and less explanatory (Portos et al., 2020), and many researchers have moved away from sociological models of voting in favor of more contextual approaches.

Lancelot (1968) conducted an introductory study seeking to explain abstentionist voting. $\mathrm{He}$ distinguished three types of factors: (1) institutional factors, related to the institutional structures and measures that govern the act of voting; (2) cyclical factors, related to the election context; and (3) structural factors, related to the profile of society and the economic, political and social systems that shape it. Here, we focus on the last category of factors.

Since Lazarsfeld's research in the United States (notably, Lazarsfeld et al., 1954, 1966) and Gaxie's research in France (1989), we know that electoral participation is linked to social conditions. Indeed, a small number of socio-demographic variables continue to be strongly associated with abstention (level of education, social class and age). In the United States, socio-demographic variables are highly 


\section{Paper accepted in International Regional Science Review}

predictive: in the 2008 presidential elections, $61 \%$ of citizens without a high school diploma abstained from voting, compared to 17\% among those with a Master's degree (Pasek et al., 2009).

While a limited number of sociological variables continue to encapsulate heterogeneity in the act of voting (Fisher et al., 2017), analysis by individual determinants does not exhaust the issue of voter turnout. Since the mid-2000s, a number of social science researchers have reinvented the contextual approach to voter behavior. The survey by Braconnier and Dormagen (2007) is a good illustration of this renewal: in a study of a neighborhood in the town of Saint-Denis, which has some of the highest unemployment and school dropout rates in France, the authors analyzed the effects of territorial characteristics on low voter turnout. They showed that areas with the highest levels of abstention rates are especially found in neighborhoods with large housing estates whose inhabitants combine, at individual level, the socio-demographic factors predisposing them to electoral withdrawal: in other words, among other things, they are younger, less educated, more often of immigrant origin and more affected by unemployment than the average person.

In his study of the 1977-78 elections in the city of Nantes, the sociologist Peneff (1981) pointed to the over-representation of abstention in the working classes, and the high turnout in middle and upper class circles. According to several authors, the abstentionist vote is thus more widespread among the working classes (Braconnier and Dormagen, 2007; Anderson and Beramendi, 2012; Lahtinen, 2017; Health, 2018). Carreras and Castañeda-Angarita (2019) used cross-sectional data from 44 countries in Africa, Asia, Europe and Latin America between 1996 and 2013 and found that individual-level attributes and structural factors shape voters' responses to economic adversity. In particular, they showed that voter turnout is generally lower among the most vulnerable socio-economic groups.

Several researchers (Hughes and Guerrero, 2009; Lahtinen et al., 2017) have asked why these most vulnerable socio-economic groups tend to vote less than others. They suggest that these people feel abandoned by politicians who do not take their needs into account. They believe that voting will not change their fate and thus display an attitude of disenchantment. People disengage from politics because they think that politicians (no matter which party is in power) will not be able to change their situation. 
Hypothesis 1: In areas where there is a concentration of politically and/or sociologically marginalized populations, there is a higher abstention rate. This hypothesis oncerns non-voters who are peripheral to political life (disenchantment attitude).

Other explanations can be offered for differences in participation. These explanations can be found, in particular, in the emerging regional science literature. It has been shown that people living in "places that don't matter" have a tendency to express their dissatisfaction at the ballot box (Gordon, 2018; Rodríguez-Pose, 2018 and 2020). Regional scientists include more contextual factors and refer to more territorial aspects. While, in the past, rural areas were associated with high voter turnout and large urban areas with high abstention (Lancelot, 1968), this relation now appears to be reversed (Roy et al., 2015; Scala and Johnson, 2017). In a comparative study between two Polish regions, Flemming (2006) showed how territorial characteristics help to explain the level of participation in elections, with people living in urban areas more likely to go to the polls than those in peripheral and rural areas. Walks (2005) also noted this in his longitudinal study of British elections between 1950 and 2001, explaining that city centers and suburbs diverged in their voting choices and participation levels in the post-war period. Similar results can be found in De Maesschalck's (2011) study of the city of Antwerp and Roy et al.'s research (2015) in the Canadian context.

Furthermore, following the paper of Rodríguez-Pose (2018), emerging literature has highlighted the fact that voting behavior depends on territorial characteristics. Regional scholars support the idea that local economic conditions shape voting behavior and that certain territorial characteristics are more conducive to certain types of voting (Los et al., 2017). They argue that the protest vote is more present in areas in decline (industrial and demographic decline, decline in public services), especially those that were once major industrial bases, but that have experienced a significant decline in employment caused by the closure of many factories due to globalization (trade booms, offshoring, automation). Here, we observe that they provide fertile ground for the anti-system/populist vote. The economic and financial crisis of 2008 only served to reinforce this phenomenon, with the subsequent austerity campaign introduced by many nations leading to a rapid decline in public services in some regions. All this has shored up the resentment of inhabitants in these regions who feel abandoned, forgotten and neglected. As a result, the 


\section{Paper accepted in International Regional Science Review}

growing anger of part of the population has found its way to the ballot box, resulting in a rejection of traditional parties in favor of a rise in populist parties (Rodríguez-Pose, 2018 and 2020).

In the context of the Brexit vote, Lee et al. (2018) showed that people living in declining jurisdictions who lacked the means to settle elsewhere (residential immobility) tended to vote to leave the EU. In the context of the Netherlands, van Leeuwen et al. (2020) demonstrated that both compositional and contextual circumstances in areas of demographic decline led to a vote of discontent. At the level of European regions, Dijkstra et al. (2020) showed that the vote for populist parties was also higher in shrinking regions. In addition, they showed that population density and the urban/rural divide played a role in the rise of extremist parties in Europe. Several researchers (Gordon, 2018; Spicer, 2018; Rodríguez-Pose, 2018) have demonstrated that people who are still well-off may live in relative comfort, but the places where they live are in decline, leaving them dissatisfied with their living conditions (due to the closure of public services in some areas, for example). This in turn results in an electoral attitude of protest. In other words, such residents feel dissatisfied with their living conditions as they earn a good living but also pay a lot of taxes (Spicer, 2018). They have the impression that they "pay for the others" and feel left behind, despite the fact that they are relatively well-off. This can also lead to abstention among the wealthy, when, from a political sociology perspective, one would expect them to be significantly involved in elections. Thus, contextual effects also play a role in explaining voting behavior. To date, regional research has not examined the abstentionist vote, despite the fact that the electoral studies literature explains that it can be a protest vote or a vote of disengagement.

Hypothesis 2: Areas with sustained economic hardship and marginalization are more likely to experience high levels of abstention. This hypothesis refers to non-voters living in peripheral/shrinking areas (contestation/discontent attitude).

Thus, the literature review gives us insights into how a geography of participation emerges. As explained in the introduction, these abstention differentials can be explained by two types of attitude: disengagement and disenchantment (hypothesis 1) or contestation (hypothesis 2). 


\section{Methodology and data}

\subsection{Study area}

Our study area was Paris and its inner suburbs. This area is highly urbanized and socially polarized. The polarization of urban structures revolves around several dimensions. We distinguish between two urban structures in particular. The first concerns the spatial distribution of social classes, marked by the abundance of "mixed middle" spaces (Préteceille, 2004) across the urban fabric and by stronger forms of polarization at both ends of the social structure. It is therefore not a dualization, but a mechanism of socio-spatial segregation at the extremities of the class structure, concerning the wealthier groups on the one hand and the highly marginalized on the other. Traditionally, the concentration of wealthy groups (here, the "executive" socio-professional category) is highest in Paris and in the western and southern suburbs of Paris, while areas where wealthy groups are relatively absent are concentrated in the east, in Seine-Saint-Denis and in the remotest peri-urban areas of Seine-et-Marne (see Map 1). A second form of segregation concerns immigrants and, implicitly, the descendants of migrants. To the north and east of the capital, there is a clear over-representation of immigrants. In the same way, immigrants are underrepresented in peri-urban areas, particularly to the east of Seine-et-Marne. In these areas, there is a disconnection between socio-spatial segregation and the segregation of immigrants, and the former do not overlap with the latter (Map 2). 
Map 1. Executives

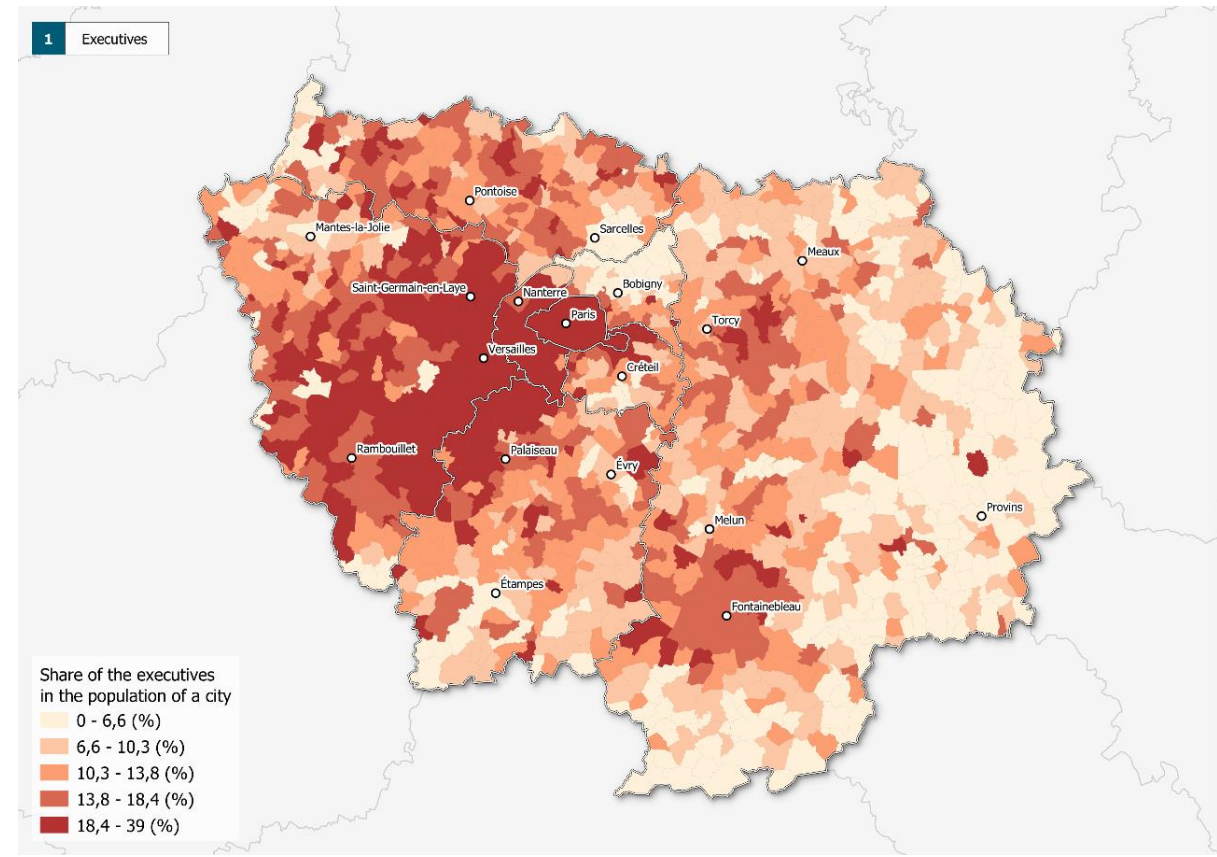

Map 2. Immigrants

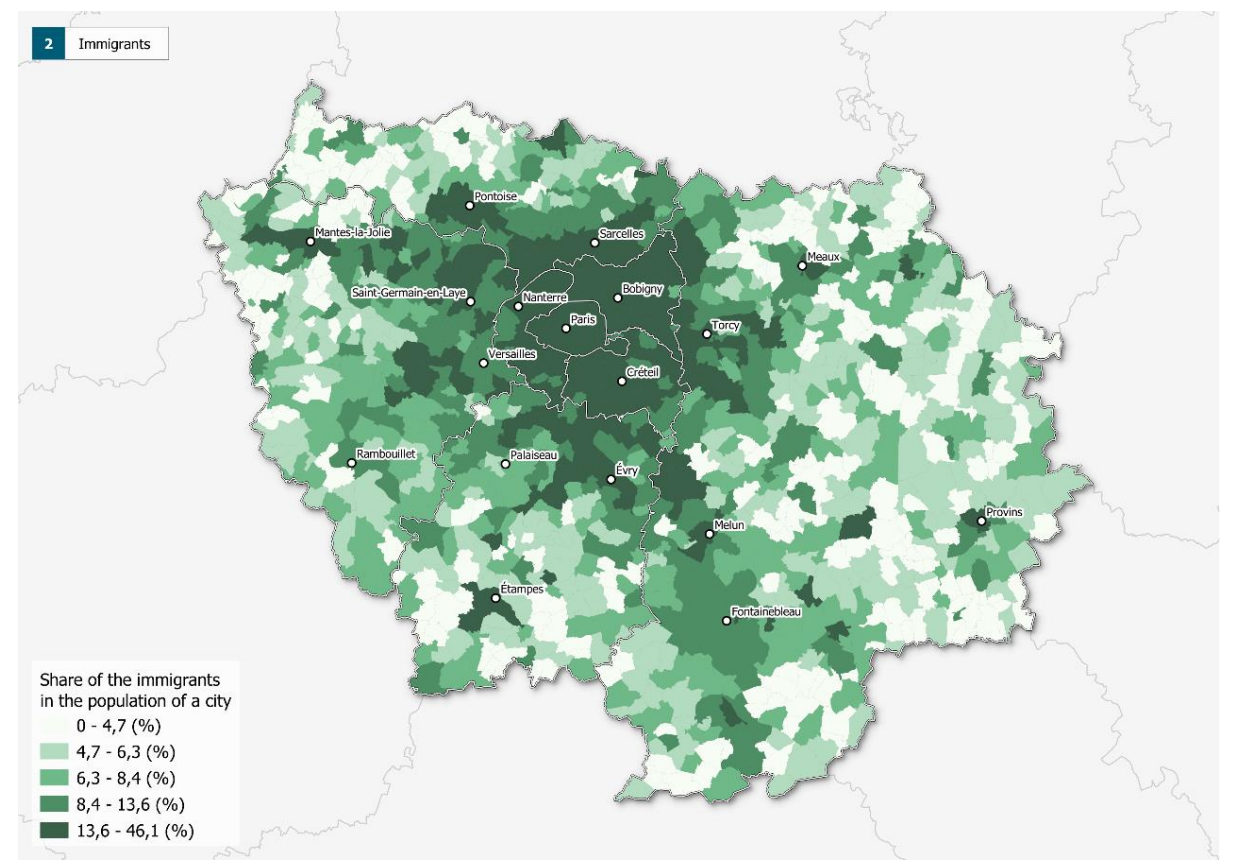


Map 3. Abstentionist voting during the last presidential elections in 2017 ( $1^{\text {st }}$ round)

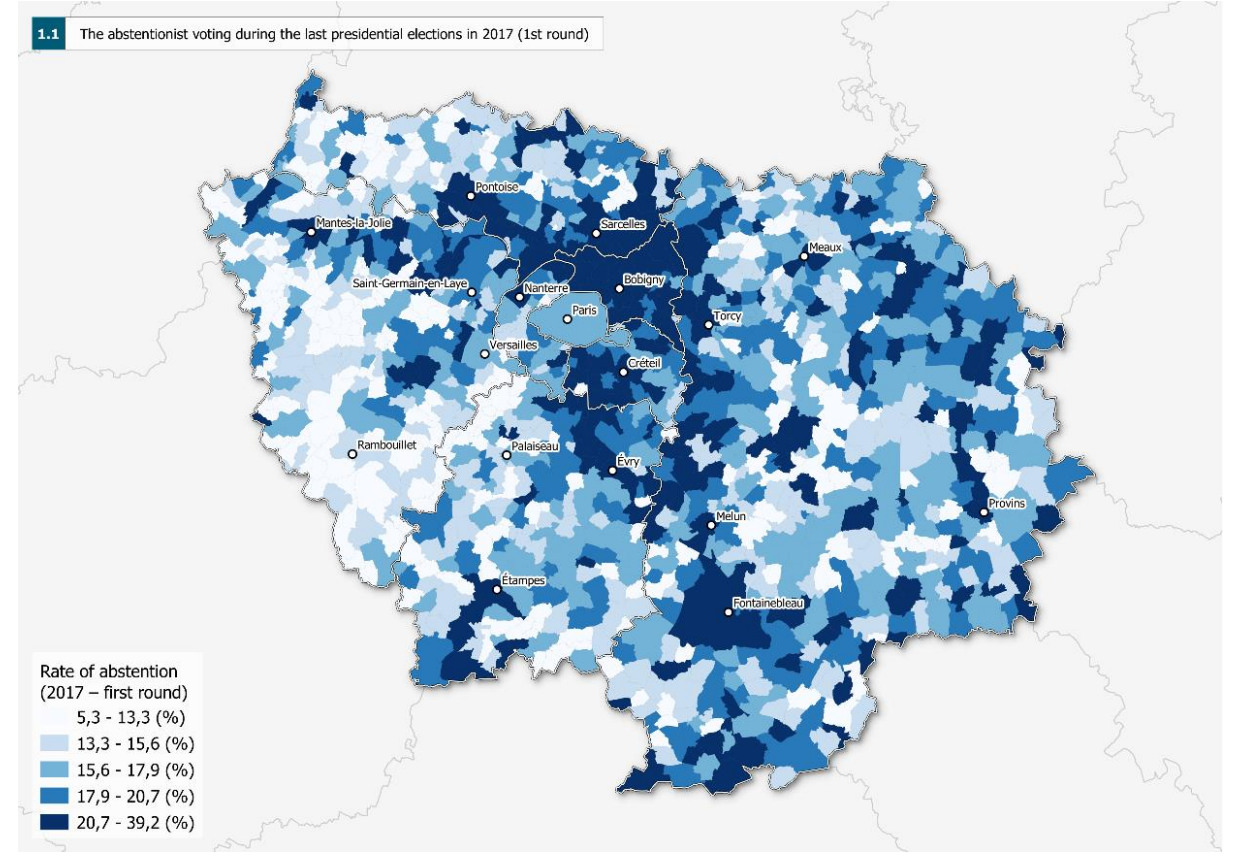

Map 4. Abstentionist voting during the last presidential elections in 2017 ( $2^{\text {nd }}$ round $)$

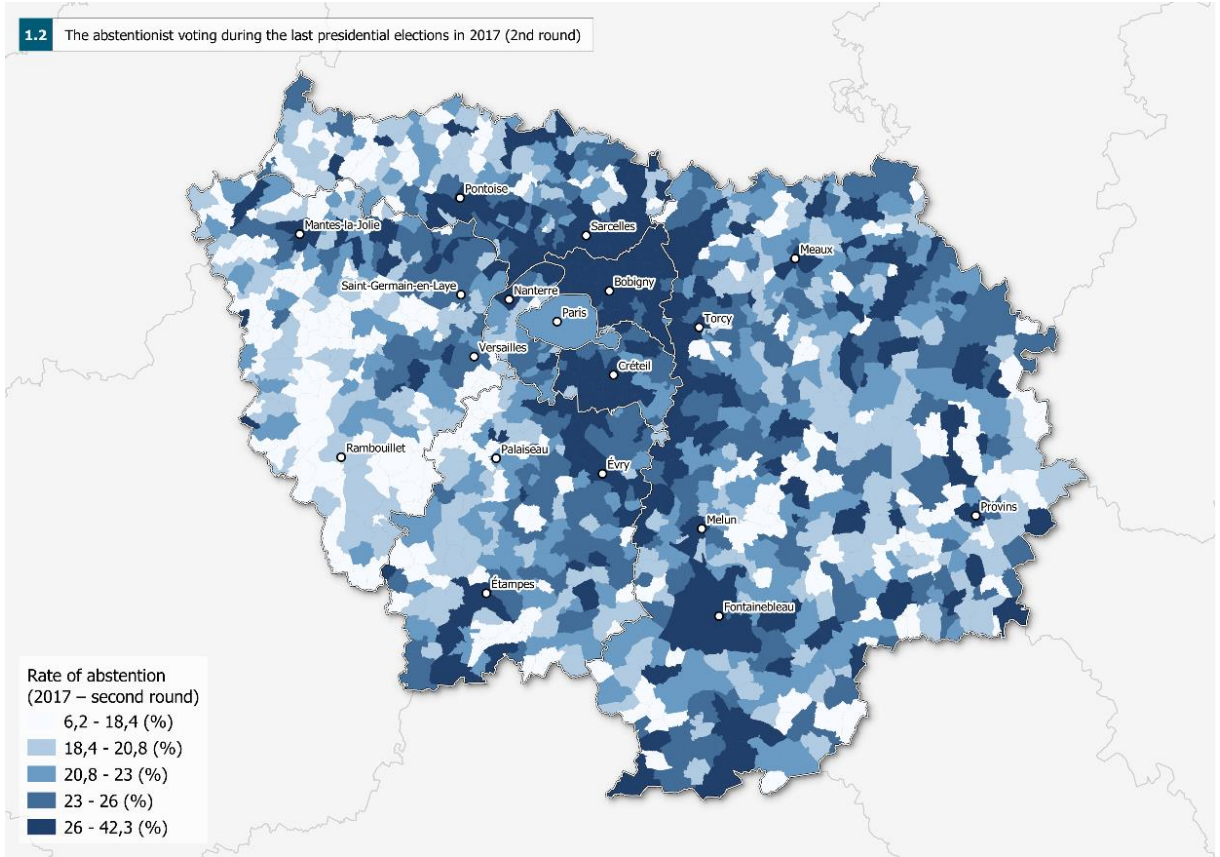




\section{Paper accepted in International Regional Science Review}

\subsection{Data}

With regard to the data incorporated into the model, our explanatory variable is the abstention rate in the first (Map 3) (Abstention R1) and second rounds (Map 4) (Abstention R2) of the last presidential elections in 2017. The abstention rate is defined as the difference between the number of registered voters and the number of voters. It shows the geographical distribution of registered voters who did not participate in the elections, thus reflecting disparities in the entrenchment of the democratic tradition in the country. We decided to study the two rounds since, in the first round of the presidential elections, there was a large political and ideological electoral offering (eleven candidates in the race), while only two candidates were left in the runoff (Emmanuel Macron - centrist; Marine Le Pen - extreme right). Vassil et al. (2016) showed that a large number of candidates significantly increases turnout since voters are more likely to endorse a political ideology similar to their own. Including both rounds thus allows us to test the results' robustness by analyzing the permanencies and differences in the effects of the regressors on the dependent variable between the first and second rounds.

The data were collected at municipal level of the Metropolis of Paris. To test our hypotheses, we first identified variables of interest, to which we added other regressors that could explain abstentionist voting. We considered these other regressors as control variables.

Table 2. Descriptive statistics

\begin{tabular}{|c|c|c|c|c|c|c|c|c|}
\hline Variable & Description & Status & Date & $\mathrm{N}$ & Min & Max & Mean & St. Dev. \\
\hline Abstention R1 & Abstention rate - Presidential elections (First round) & Explained & 2017 & 1268 & 5.3 & 39.2 & 17.27 & 4.83 \\
\hline Abstention R2 & Abstention rate - Presidential elections (Second round) & Explained & 2017 & 1268 & 6.2 & 42.3 & 22.32 & 4.88 \\
\hline Immig & Share of immigrants in the population & Hypoth. 1 & 2016 & 1268 & 0 & 46.1 & 9.6 & 6.87 \\
\hline PubHou & Share of public low-rent housing & Hypoth. 1 & 2016 & 1268 & 0 & 64.3 & 8.05 & 11.99 \\
\hline EvoEquip & Evolution of the equipment rate of cities & Hypoth. 2 & $2007-2016$ & 1268 & 0 & 117.3 & 16.77 & 8.88 \\
\hline Unemploy & Unemployment rate (18-64yo) & Control & 2016 & 1268 & 0 & 25.9 & 9.62 & 3.51 \\
\hline Ехеси & Share of executives in the working age population & Control & 2016 & 1268 & 0 & 39 & 12.87 & 7.04 \\
\hline HighEduc & Share of the population with a higher education diploma & Control & 2016 & 1268 & 9.3 & 72.6 & 34.01 & 11.52 \\
\hline yo20to 24 & Share of 20-24 yo. in the population & Control & 2016 & 1268 & 0 & 30.59 & 5.07 & 1.6 \\
\hline plus65yo & Share of the population over 65 years old. & Control & 2016 & 1268 & 3.8 & 51.8 & 15.51 & 4.48 \\
\hline
\end{tabular}

First, we identified several variables related to our hypotheses. Regarding the first hypothesis, we identified two variables that referred to socio-economic marginalization. We then added the share of 
immigrants ${ }^{3}$ in the population (Immig). Soininen and Bäck (1999) found that, beyond national contexts and circumstances, when immigrants have obtained their new nationality and are eligible to vote, their participation is lower than that of "born-nationals." From a theoretical perspective, studies on political incorporation point to a lower propensity to vote due to the political repression immigrants often experienced in their home countries. As a result, they tend to be more distrustful of the existing political system. In addition, they have much lower awareness of the political offer and do not consider themselves to be a "priority" public in terms of public policies. Consequently, they feel that voting will not necessarily serve to improve their cause. We also added another variable to our first hypothesis: the share of low-rent public housing (PubHou). Many authors, including Hunt (2018), have argued that public housing can be considered the archetype of urban marginalization. Low-cost housing is offered to populations in socio-economic difficulty and is often located on the outskirts of cities, reinforcing the phenomenon of socio-spatial eviction. In a recent study applied to the Chinese case (Xu and Luo, 2021), the authors confirmed that recently developed social housing projects promote urban ghettoization, generating a negative spiral for those who live there. Residents feel powerless as, on the one hand, they observe that public policies are introduced, but on the other hand, find them to be ineffective. As a result, they reject politics more often than other groups as their aspirations are not understood or taken into consideration in public policy design (disenchantment attitude), so they tend to think that voting is a "waste of time" (Leighley and Nagler, 2013).

Regarding the second hypothesis, according to the recent work of several researchers (Gordon, 2018; Spicer, 2018; Rodríguez-Pose, 2018; Dijkstra et al., 2020), people living in declining areas tend to cast more protest votes. This may include wealthy people living in relative comfort, but in areas in decline, who are therefore dissatisfied with their living conditions and consequently have a protest attitude towards electoral participation. It may also encompass socially disadvantaged populations who live in shrinking areas and attempt to make their voice heard by rejecting politics. In both cases, by not voting, they want to send a strong signal to politicians. They do not feel included in the politicians' proposals

\footnotetext{
${ }^{3}$ An immigrant is a person born abroad with foreign nationality and residing in France. Individuals born abroad, but who are French and living in France are therefore not counted. Some immigrants may subsequently become French through acquisition of the nationality, while others remain foreigners (INSEE).
} 
for improvement, and would rather abstain than vote for someone who is unlikely to improve their living conditions. To approximate territorial decline, we included a variable relating to the evolution of the equipment (amenity) rate ${ }^{4}$ in cities between 2007 and 2018 (EvoEquip). Municipalities with a reduction in the number of basic services for the population can be considered as in decline.

Second, we identified other variables, considered as control variables, found in the traditional literature on voter turnout, which can have positive or negative effects on electoral participation. The share of executives in the working age population (Execu) and the share of the population with a higher education degree $(H i g h E d u c)$ is expected to have a negative effect on abstention. Since interest in institutional politics remains - in France and elsewhere - strongly correlated with educational attainment (Delli Carpini and Keeter, 1996; Burden, 2009), voter turnout traditionally varies in relation to this factor. Education helps to provide civic skills and to form political opinions. The literature on voter turnout discussed above has broadly shown that more socially integrated people tend to go to the polls because they are more politically literate and have social and political networks that encourage them to vote. The unemployment rate (Unemploy) is more ambiguous in the literature on voter participation. Indeed, while, studies in electoral sociology traditionally show that social isolation associated with inactivity decreases the likelihood that the unemployed will engage in politics, studies (such as that by Burden and Wichowsky (2014) in the U.S.) suggest that high unemployment is a key participation factor.

We also added demographic variables to the control variables. Age is a traditional factor in participation, and the observation that young people vote less than older citizens is not new. Since electoral mobilization is an extension of other forms of social integration, it has long been acknowledged that there is an increase in the level of participation of individuals who enter the world of work, find stability, and build a family (Arzheimer et al., 2016). The longer duration of studies, on the one hand, together with unemployment, which massively affects less qualified, younger people, on the other hand, could

\footnotetext{
${ }^{4}$ The permanent equipment base (INSEE) is intended to measure the level of equipment and services each region provides to the population. It consists of the following facilities: savings banks, driving schools, hairdressers, restaurants, police, gendarmerie, post offices, post office relays, post office agencies, supermarkets, bakeries, bookshops, newspaper and stationery outlets, petrol stations, grocery shops, mini-markets, colleges, nursery schools, primary schools, general practitioners, dental surgeons, nurses, pharmacies, medical analysis laboratories, assistance services for the elderly and pre-school childcare.
} 


\section{Paper accepted in International Regional Science Review}

thus explain the considerable degree of abstention recorded in the youngest age groups, particularly in the 18-35-year-old age group. Researchers have also pointed to a possible generation effect that is even more worrying for the future: less exposed than their elders to the participationist norm, individuals born between 1980 and 1996 may not evolve towards the participation model as consistently as the over-50s that vote today (Tiberj, 2013). Conversely, voter turnout among seniors is generally higher. They have a stronger civic consciousness and constitute a coveted electorate for the different parties. They are therefore often targeted as potential voters. Accordingly, we added the following variables: the share of 20-24-year-olds in the population (20to24yo) and the share of over 65 year olds (over65yo). Finally, we added an exogenous covariate. Electoral studies highlight the difficulty of finding exogenous variables. Following Hansford and Gomez (2010), however, we decided to use weather. Gomez et al. (2007) showed that bad weather on election day is associated with lower levels of voter turnout, and since bad weather is clearly exogenous to election outcomes, we opted to use this variable.

\subsection{Econometric specification}

Since the starting point in studying the link between socio-spatial segregation and abstentionism is the spatial structuring of inequalities, our study aimed to highlight the existence of spatially structured inequality in electoral participation. We also believe that there is a specific effect of spatially belonging to certain neighborhoods on voter registration and participation. In other words, the aim was to identify the share of territorial inequalities in voter participation that is directly related to the specific sociological composition of the areas studied. This hypothesis allowed us to reintroduce the spatial dimension into the framework of sociological voting models. Marginalization is not simply considered here as one explanatory factor among others. Rather, it appears to constitute a specific crucible that establishes relations between all the traditional sociological variables, making it possible to understand the production of local contexts from the always singular configurations of the effects of class, national or ethnic origin, religion, qualifications or age (Mur et al., 2012; Lacombe et al., 2014). Given our geographical approach, we took into account the relative position of the areas studied at least as much as their specific socio-economic characteristics. 


\section{Paper accepted in International Regional Science Review}

Another aspect of abstentionist voting - and voter behavior more generally - is that certain 'contextual' variables influence voter behavior in surrounding neighborhoods. From a theoretical point of view, several mechanisms can explain how voting behavior is influenced by neighborhood effects (Cox, 1969; Johnston et al., 2004; Weaver, 2014): (i) people living nearby tend to interact with each other more and thus influence their neighbors' behaviors; (ii) people tend to choose neighborhoods where the residents are similar to them (socio-economic level, values and political attitudes); (iii) people tend to conform to the majority choices of their neighbors; (iv) people make political choices that will maintain or improve existing local conditions; (v) political candidates campaign in specific geographic territories; and (v) as political candidates campaign in specific geographic areas, the people living there may be influenced by such campaign efforts and thus respond in kind. From an empirical perspective, several studies on absenteeism confirm what is expected from a theoretical point of view. Using the U.S. electoral context, Enos (2016) demonstrated that, consistent with psychological theories of racial threat, white voter turnout was influenced by their greater or lesser proximity to racialised populations. Gimpel et al. (2004) studied abstentionist voting in counties in the United States during the 2000 presidential elections and showed that the geographic context affects voter turnout, highlighting neighborhood effects between counties. Yandri (2017) reached a similar conclusion from an analysis of local elections in peri-urban areas in Indonesia which showed that there is a spatial autocorrelation of non-voters in peripheral and peri-urban areas. These theoretical arguments and empirical results justify the need to take these neighborhood effects into account.

Consequently, following electoral geography theorists that have identified neighborhood effects in voting behavior, we introduced a spatial model to explain abstention. This spatial model is justified by theoretical issues and substantiates the use of the following tests for statistical reasons (first part of the results).

The econometric specification considered in this research takes the linear regression model of ordinary least squares (OLS) as its starting point:

$\mathrm{Y}=\mathrm{X} \beta+\varepsilon$ 
$\mathrm{Y}$ is the dependent variable (abstention rate in 2017 or the evolution of the abstention rate between 1995 and 2017). X represents the explanatory variables used, $\beta$ is the vector of parameters to be estimated, and $\varepsilon$ is the error term.

When a spatial autocorrelation phenomenon is ignored in the model specification but is present in the data-generating process, the OLS estimators are biased and non-convergent. The spatial autoregressive (SAR) model consists of correcting this bias by integrating an "endogenous shifted variable" WY into model (1) and taking into account the spatial autocorrelation relative to the variable Y. The model is written as follows:

$\mathrm{Y}=\rho W \mathrm{Y}+\mathrm{X} \beta+\varepsilon$

WY is the shifted endogenous variable for the spatial weighted matrix $\mathrm{W}^{5}$, and $\rho$ is the autoregressive parameter, indicating the intensity of the existing interaction between the observations of $\mathrm{Y}$. In this model, the observation of $\mathrm{Y}$ is partly explained by the values taken by $\mathrm{Y}$ in neighboring cities. The introduction of the variable WY in model (1) allows us to assess the degree of spatial dependence, while the other variables are controlled. Symmetrically, it allows spatial dependence to be controlled in order to assess the impact of the other explanatory variables. An intuitive approach would be to estimate model (2) using OLS. However, this results in a biased and inconsistent estimate, even when the residuals exhibit normality (Anselin, 1988). Due to this issue with the OLS estimator, spatial models are usually estimated using the maximum likelihood estimator (MLE). Hence, consistent with the literature, we use the same estimation methods.

A second way of incorporating spatial autocorrelation into econometric models is to use the spatial error model (SEM), which consists of specifying a spatial dependence of errors process in a regression model. The SEM model is defined as follows:

$\mathrm{Y}=\mathrm{X} \beta+\varepsilon$ with $\varepsilon=\lambda \mathrm{W} \epsilon+\mathrm{u}$

\footnotetext{
${ }^{5}$ Regarding the choice of the spatial weighting matrix, following Stakhovych and Bijmolt (2009), we used the loglikelihood function value (LIK). The most appropriate spatial weighting matrix is the $2^{\text {nd }}$-order contiguity (highest LIK).
} 


\section{Paper accepted in International Regional Science Review}

Parameter $\lambda$ reflects the intensity of interdependence between the regression residuals, and $u$ is the error term. Omitting the spatial autocorrelation of errors produces unbiased but inefficient estimators, so statistical inference based on OLS will be biased.

According to Rey and Le Gallo (2009), different approaches can be used for the model selection. We chose the so-called bottom-up approach, which consists of starting with the non-spatial model. Lagrange multiplier tests (Anselin et al., 1996) then make it possible to decide between the SAR, SEM, and nonspatial models. The choice is made between the three models by comparing the significance levels of the Lagrange multiplier tests (LMError, LMLag) and their robust versions (RLMError and RLMLag). If LMLag is as significant as the LMError and only RLMLag is significant, a lagged endogenous variable is included, and the preferred model will be the SAR. Conversely, if LMerror is as significant as LMLag, and only RLMError is significant, then the model with error autocorrelation (SEM) is chosen (Le Gallo, 2002). If none of the tests are significant, the OLS model should be used.

However, LeSage (2014) points to the need to broaden the choice of models in order to first consider either a spatial Durbin model (SDM) or a Spatial Durbin Error Model (SDEM), depending on whether a global or local spillover specification is more appropriate for the study. Since the study is interested in the spillover impact of commune-level abstention rates arising from nearby commune characteristics versus those that are further afield, a local spillover specification is more suitable. We therefore estimate an SDEM rather than an SDM. The SDEM is defined as follows:

$\mathrm{Y}=\mathrm{X} \beta+\mathrm{WX} \theta+\varepsilon$ with $\varepsilon=\lambda \mathrm{W} \epsilon+\mathrm{u}$

This is essentially a generalization of the SEM with parameter $\theta$ from the spatially shifted/lagged exogenous variable WX. Put another way, the SDEM is also a generalization of another simpler model, which is called the spatial lag of X model (SLX):

$\mathrm{Y}=\mathrm{X} \beta+\mathrm{WX} \theta+\varepsilon$

Thus, the choice revolves around the four models (OLS, SEM, SLX, and SDEM), and everything depends on whether or not the SDEM can be simplified to an OLS, SEM, or SLX model. The basis of such a decision depends on whether the parameters $\theta$ and/or $\lambda$ are zero. Due to the maximum likelihood 


\section{Paper accepted in International Regional Science Review}

estimation procedure in estimating an SDEM, we base our hypothesis testing on likelihood ratio tests, consistent with the literature, such as LeSage and Pace (2009).

\subsection{Precautions in interpreting the data}

A recurring issue in the interpretation of data in electoral geography is the ecological paradox. This paradox, noted by Robinson in 1950, highlights the impossibility of postulating individual behaviors from aggregate data. In the study of electoral behavior in France, for example, an ecological error is found in the presence of a strong correlation between the Maghreb population rate and higher scores of the National Front (extreme right). Given this result, it would be somewhat foolhardy to deduce that Maghrebians vote more often for a political party whose discourse and practices are hostile to them. Instead, studies show that it is in the margins (neighborhoods of intermediate social strata) of areas with a higher immigrant population where support for the National Front is found (Bon and Cheylan, 1988). This spurious correlation lies in the presence of confounding factors within the spatial units used. Thus, in the study of extreme right-wing voting, it is the proximity of the Maghreb populations that incites many citizens to support the National Front (Bussi, 1998). This example illustrates the main criticism of ecological analysis: that of considering collective correlations as individual correlations.

In order to minimize or avoid this potential misinterpretation of the results produced by an ecological analysis, we considered the independent variables not as direct individual determinants, but as generating a specific social context that induces a political context (Bussi, 1998). This consideration thus makes it possible to highlight certain spatial factors and social relations.

\section{Results}

Table 3 presents the regression results of the four primary models based on the so-called bottom-up approach. We estimated two OLS models; the first, the base model, does not incorporate a spatial dimension, while the second builds on this model by integrating an endogenous shifted variable (the spatially lagged dependent variable) in order to make it more comparable with the two spatial models estimated, namely the SAR and the SEM. The difference between the second model and the SAR is that while the second model was estimated using OLS, the latter was estimated using MLE and is hence 


\section{Paper accepted in International Regional Science Review}

more appropriate, as discussed in the previous section. Moving on to Table 4, which reports the results of the spatial diagnostic tests on the OLS model, we see evidence of spatial dependencies having very significant Moran's I statistics, thereby rejecting the null hypothesis of no spatial autocorrelation at the 5\% alpha. Furthermore, we see that the Lagrange multiplier (LM) and its robust (RLM) test version points to the use of an SEM rather than an SAR for both models. Thus, the bottom-up approach led us to choose the SEM as our preferred model. The Akaike information criterion (AIC) found at the bottom of Table 3 likewise supports the decision to choose the SEM over the SAR, since the SEM for our model yields a lower AIC.

However, as discussed in the previous sections, the bottom-up approach may not always yield the best outcome as it narrows the choice down to just three models (OLS, SAR, and SEM), when in fact the best model could be none of the three presented. Hence, Table 5 reports the likelihood ratio tests on the SDEM, and we can reject the null hypothesis that the SDEM is restricted to one of the three models (SEM, SLX, or OLS) at the 5\% alpha. Thus, the preferred model for the Abstention case is the SDEM. As indicated in Table 6, the Breusch-Pagan statistic (0.002) allows us to reject the hypothesis of correlation between the independent variables and the error term, and the variance inflation factor (VIF) ${ }^{6}$ confirms that multicollinearity is not an issue. Given this, we now read our estimation results for the SDEM, keeping in mind the caution required regarding their interpretation, as discussed in the previous section.

\footnotetext{
${ }^{6}$ The maximum is for capacities with a VIF of 5.32 (i.e., the standard error for the coefficient of this predictor variable is 2.36 times larger than if the predictor variable had 0 correlation with the other predictor variables).
} 
Table 3. Regression results

\begin{tabular}{|c|c|c|c|c|c|c|c|c|}
\hline \multirow{3}{*}{ Estimation methods } & & & & & & & & \\
\hline & $(1)$ & $(2)$ & (3) & $(4)$ & $(5)$ & $(6)$ & (7) & $(8)$ \\
\hline & OLS & OLS & SAR & SEM & OLS & OLS & SAR & SEM \\
\hline Lag. Abstention & & $0.098 * * *$ & & & & $0.099 * * *$ & & \\
\hline Immig & $0.124 * * *$ & $0.090 * * *$ & $0.103 * * *$ & $0.111 * * *$ & $0.121 * * *$ & $0.102 * * *$ & $0.114 * * *$ & $0.120 * * *$ \\
\hline PubHou & $-0.171 * * *$ & $0.179 * * *$ & $0.178 * * *$ & $-0.173 * * *$ & $-0.170 * * *$ & $-0.174 * * *$ & $-0.177 * * *$ & $-0.172 * * *$ \\
\hline EvoEquip & $0.094 * * *$ & $0.099 * * *$ & $0.102 * * *$ & $0.995 * * *$ & $0.075 * * *$ & $0.079 * * *$ & $0.087 * * *$ & $0.084 * * *$ \\
\hline Unemploy & $0.214 * * *$ & $0.189 * * *$ & $0.194 * * *$ & $0.199 * * *$ & $0.228 * * *$ & $0.230 * * *$ & $0.239 * * *$ & $0.228 * * *$ \\
\hline Execu & $-0.124 * *$ & $-0.129 * *$ & $-0.128 * *$ & $-0.131 * *$ & $0.055^{* *}$ & $0.067 * *$ & $0.064 * *$ & $0.069 * *$ \\
\hline HighEduc & $-0.105^{* * *}$ & $-0.109 * * *$ & $-0.109 * * *$ & $-0.111 * * *$ & $-0.139 * * *$ & $-0.143 * * *$ & $-0.140 * * *$ & $-0.140 * * *$ \\
\hline yo20to24 & $0.072 * *$ & $0.075^{* *}$ & $0.69 * *$ & $0.073 * *$ & $0.147 * *$ & $0.149 * *$ & $0.138 * *$ & $0.137 * *$ \\
\hline plus65yo & $-0.004 * *$ & $-0.005 * *$ & $-0.005 * *$ & $-0.004 * *$ & $0.083 * * *$ & $0.085 * * *$ & $0.081 * * *$ & $0.086 * * *$ \\
\hline$\rho$ & & & $0.137 * * *$ & & & & $0.152 * * *$ & \\
\hline$\lambda$ & & & & $0,214 * * *$ & & & & $0,199 * * *$ \\
\hline Observations & 1268 & 3268 & 5268 & 7268 & 2268 & 4268 & 6268 & 8268 \\
\hline Adjusted R² & 0.57 & 0.563 & & & 0.581 & 0.587 & & \\
\hline Pseudo $\mathrm{R}^{2}$ & & & 0.582 & 0.585 & & & 0.596 & 0.601 \\
\hline Akaike Inf. Crit. & & & 6257.819 & 6241.536 & & & 6258.351 & 6240.845 \\
\hline Log Likelihood & & & -3542.628 & -3531.012 & & & -3540.965 & -3522.949 \\
\hline
\end{tabular}
$* p<0.1 ; * * p<0.05 ; * * * p<0.01$

Table 4. Diagnostic tests

\begin{tabular}{lcc} 
& \multicolumn{2}{c}{ OLS (without any spatial lags) } \\
\cline { 2 - 3 } & Abstention R1 & Abstention R2 \\
\hline Moran's I & $0.389^{* * *}$ & $0.377^{* * *}$ \\
LMlag & $18.549^{* * *}$ & $17.690^{* * *}$ \\
LMerr & $28.985^{* * *}$ & $26.391 * * *$ \\
RLMlag & 0.140 & 0.132 \\
RLMerr & $8.444 * * *$ & $8.831^{* * *}$ \\
\hline
\end{tabular}

Table 5. Likelihood ratio tests

\begin{tabular}{lcc} 
& \multicolumn{2}{c}{ SDEM } \\
\cline { 2 - 3 } & Abstention R1 & Abstention R2 \\
\hline$H_{0}: \theta=0$ & $41.351^{* * *}$ & $43.21^{* * *}$ \\
$H_{0}: \lambda=0$ & $17.692^{* * *}$ & $16.259^{* * *}$ \\
$H_{0}: \lambda=0, \theta=0$ & $67.456^{* * *}$ & $68.39^{* * *}$ \\
\hline
\end{tabular}


Table 6. Regression results (SDEM)

\begin{tabular}{|c|c|c|c|c|c|c|c|c|}
\hline & \multicolumn{4}{|c|}{ Abstention R1 } & \multicolumn{4}{|c|}{ Abstention R2 } \\
\hline & $(1)$ & (2) & (3) & (4) & $(5)$ & $(6)$ & (7) & $(8)$ \\
\hline Immig & $0.138 * * *$ & & & $0.122 * * *$ & $0.138 * * *$ & & & $0.120 * * *$ \\
\hline РubHou & & $0.088 * * *$ & & $0.085^{* * *}$ & & $0.081 * * *$ & & $0.093 * * *$ \\
\hline EvoEquip & & & $-0.151 * * *$ & $-0.166 * * *$ & & & $-0.187 * * *$ & $-0.185 * * *$ \\
\hline Unemploy & $0.214 * * *$ & $0.189 * * *$ & $0.194 * * *$ & $0.199 * * *$ & $0.228 * * *$ & $0.230 * * *$ & $0.239 * * *$ & $0.228 * * *$ \\
\hline Execu & $-0.135^{* *}$ & $-0.141 * *$ & $-0.136 * *$ & $-0.130 * *$ & $0.057 * *$ & $0.054 * *$ & $0.061 * *$ & $0.058 * *$ \\
\hline HighEduc & $-0.110 * * *$ & $-0.108 * * *$ & $-0.114 * * *$ & $-0.111 * * *$ & $-0.132 * * *$ & $-0.134 * * *$ & $-0.139 * * *$ & $-0.137 * * *$ \\
\hline yo20to 24 & $0.071 * *$ & $0.074 * *$ & $0.072 * *$ & $0.069 * *$ & $0.145^{* *}$ & $0.144 * *$ & $0.139 * *$ & $0.140 * *$ \\
\hline plus65yo & $-0.004 * *$ & $-0.004 * *$ & $-0.003 * *$ & $-0.004 * *$ & $0.085^{* * *}$ & $0.081 * * *$ & $0.084 * * *$ & $0.083 * * *$ \\
\hline $\mathrm{W} * \mathrm{Immig}$ & $0.119 * * *$ & & & $0.112 * * *$ & $0.124 * * *$ & & & $0.120 * * *$ \\
\hline W*PubHous & & $0.087 * * *$ & & $0.076 * * *$ & & $0.082 * * *$ & & $0.072 * * *$ \\
\hline $\mathrm{W}^{*}$ EvoEquip & & & $-0.185 * * *$ & $-0.182 * * *$ & & & $-0.191 * * *$ & $-0.190 * * *$ \\
\hline $\mathrm{W}^{*}$ Unemploy & $0.212 * * *$ & $0.190 * * *$ & $0.191 * * *$ & $0.198 * * *$ & $0.224 * * *$ & $0.227 * * *$ & $0.231 * * *$ & $0.234 * * *$ \\
\hline W*Execu & $-0.128 * *$ & $-0.127 * *$ & $-0.119 * *$ & $-0.125^{* *}$ & $0.056 * *$ & $0.059 * *$ & $0.054 * *$ & $0.057 * *$ \\
\hline $\mathrm{W}^{*}$ HighEduc & $-0.103 * * *$ & $-0.102 * * *$ & $-0.102 * * *$ & $-0.109 * * *$ & $-0.132 * * *$ & $-0.137 * * *$ & $-0.136 * * *$ & $-0.134 * * *$ \\
\hline W*yo20to 24 & $0.072 * *$ & $0.075 * *$ & $0.69 * *$ & $0.073 * *$ & $0.147 * *$ & $0.149 * *$ & $0.138 * *$ & $0.137 * *$ \\
\hline W*plus65yo & $-0.009 * *$ & $-0.009 * *$ & $-0.007 * *$ & $-0.008 * *$ & $0.080 * * *$ & $0.074 * * *$ & $0.082 * * *$ & $0.079 * * *$ \\
\hline Constant & $18.105 * * *$ & $18.652 * * *$ & $19.598 * * *$ & $19.326 * * *$ & $19.395 * * *$ & $20.224 * * *$ & $20.362 * * *$ & $19.554 * * *$ \\
\hline$\lambda$ & $0.201 * * *$ & $0.194 * * *$ & $0.197 * * *$ & $0.215 * * *$ & $0.188 * * *$ & $0.192 * * *$ & $0.195 * * *$ & $0.199 * * *$ \\
\hline Observations & 1268 & 3268 & 5268 & 7268 & 2268 & 4268 & 6268 & 8268 \\
\hline Pseudo $\mathrm{R}^{2}$ & 0.547 & 0.565 & 0.562 & 0.589 & 0.583 & 0.598 & 0.604 & 0.621 \\
\hline Akaike Inf. Crit. & 6249.455 & 6253.471 & 6257.819 & 6241.536 & 6257.215 & 6251.665 & 6258.351 & 6240.845 \\
\hline Log Likelihood & -3540.226 & -3539.147 & -3542.628 & -3531.012 & -3554.361 & -3518.612 & -3540.965 & -3522.949 \\
\hline Multicollinearity & 5.10 & 5.29 & 5.30 & 5.32 & 5.23 & 5.29 & 5.44 & 5.48 \\
\hline Breush-Pagan test & $22.359 * * *$ & $22.473 * * *$ & $22.312 * * *$ & $22.423 * * *$ & $24.517 * * *$ & $24.362 * * *$ & $24.124 * * *$ & $24.995 * * *$ \\
\hline
\end{tabular}

We identified two variables (Immig, PubHou) that describe areas with socio-economic difficulties. Abstention in these territories, which is about 10 points higher than the national average, reflects the extent of the indifference and skepticism that characterizes the relationship with politics in this type of environment that is particularly exposed to social precarity. Our results support the hypothesis that socially and politically marginalized populations are more likely to abstain. It is as if the left/right alternation, in place since 1981 without any improvement in the population's living conditions, has ended up producing a strong feeling of pointlessness with regard to voting (disenchantment attitude). Thus, we can say that an unfavorable territorial context can be the catalyst for disengagement, leading to abstention. In underprivileged neighborhoods in 2007 , the political offer embodied by Nicolas Sarkozy generated the exceptional mobilization of both those supporting him - especially among voters close to the right or the Rassemblement National (extremist party) - and, on the contrary, those opposing him, above all, large sections of young people who perceived him as a hostile figure. Since then, the logic of abstention has regained the upper hand. 


\section{Paper accepted in International Regional Science Review}

Our results support the idea that abstention can also be interpreted as a protest vote. In this case, people use the decision not to go to the polls to show their dissatisfaction with politicians. People living in municipalities that experience above-average growth in basic local services over the long term tend to abstain less than those who experience a relative decline in local equipment and services. This abstention can be interpreted as a non-voting protest of people who live in areas that have been left behind, in other words, populations that have experienced a decline in the number of local shops/stores and in the supply of public services (linked to the closure of schools, police stations and post offices). This situation directly relates to the emerging literature in regional science on places that are left behind or that appear not to matter (Rodríguez-Pose, 2018). The resulting discontent of people living in these places may lead them to use the ballot box as a sign of protest. This protest vote results from the fact that such people feel dissatisfied with their living conditions (Spicer, 2018). They are not necessarily in social difficulty and often have a job (upper-middle class), but they have the impression that they pay a lot of taxes and yet see a decline in public services in their municipality, leading to the feeling that the fiscal pressure they are under is unfair. Consequently, we can postulate that an unfavorable territorial context marked by a relative decline in local amenities and services can be the catalyst for an electoral protest attitude.

Among the traditional variables explaining participation are those related to age. Our results indicate that young people tend to abstain, confirming several previous studies (including Arzheimer et al., 2016), according to which young people are often less involved in working life or even feel forgotten by public policies, especially those involving support for employment after graduation. Another explanation concerns the nature of the political parties of the two candidates in the second round (Marine Le Pen (Rassemblement National) and Emmanuel Macron (En Marche) $)^{7}$. Since the parties likely to attract very young voters (primarily ecological lists) did not make it through to the second round, young voters abstained from voting for either party. The two candidates contesting the second round may also explain why we observe a positive and significant relationship between older people and abstention. Since older people traditionally vote for the major political parties (socialist-left, republican-right), they also found themselves siding with neither candidate in the second round. This was confirmed in a study

\footnotetext{
${ }^{7}$ The election was marked by historic abstention (25.4\%). One in four voters did not go to the polls, and the record for abstention for he runoff in the presidential elections was broken for the first time since 1969.
} 


\section{Paper accepted in International Regional Science Review}

by the Ipsos Institute on the sociology of voters in the second round of the presidential elections ${ }^{8}$. Abstention was significantly higher among employees/workers (30\% abstention), the unemployed (35\%), and the least affluent households (34\%).

Another traditional factor is level of education. Our model shows a strongly negative and significant effect in both rounds, confirming previous studies on the role of level of education (Delli Carpini and Keeter, 1996; Burden, 2009) in electoral participation. People with a higher level of education have the strongest sense of civic duty and continue to visit the ballot box. Concerning unemployment, our findings show that people who live in areas with a high unemployment rate are more likely to abstain. This is consistent with the regional science literature, which has shown that people's perception of the impossibility of social mobility generates a sense of living in a place that is not only "left behind" but in which they are "stuck behind" (Lee et al., 2018; Tubadji et al., 2021). This perception of living in areas of relative deprivation consequently triggers resentment.

An interesting finding concerns executives. While we observed the expected negative and significant sign in the first round, confirming that executives are traditionally active in political life, this sign was reversed in the second round. This may at first seem counterintuitive, but it can be explained. A first explanation lies in the choices - in terms of the political offer - available to them in the second round. Vassil et al. (2016) showed that a large number of choice alternatives significantly increases turnout since voters are more likely to endorse a political ideology similar to their own. Thus, in the first round, executives were able to vote for their preferred party given the large political offering. In the second round, however, since they tend to vote for the republican right-wing, executives did not find themselves reflected in the political offer (a far-right candidate versus a centrist candidate). Consequently, some of them decided not to vote in the second round. These results are confirmed in the study by the Ipsos Institute.

Finally, lambda (spatial parameter in the residuals) is significant at the $1 \%$ alpha. Hence, neighbor characteristics indeed appear to matter. When the residuals of one's neighbor are higher by 1 unit on

\footnotetext{
${ }^{8} \mathrm{https}: / / \mathrm{www}$.ipsos.com/fr-fr/2nd-tour-presidentielle-2017-sociologie-des-electorats-et-profil-desabstentionnistes
} 
average, then one's own residual will be higher by 0.199 units (second round), meaning that unobserved factors that positively/negatively influence abstention voting in one's neighbors positively/negatively affect one's commune by half.

\section{Discussion : from electoral geography to regional science}

Following Goodchild et al.'s (2000) call for more interdisciplinary research that takes the spatial approach into account, our aim was to reintroduce the spatial dimension into political science and the sociology of voting models. Our findings suggest that the approach developed in regional science goes further than research in electoral geography. Electoral geography studies the electoral outcomes of a given region in terms of their spatial distribution. It mainly focuses on the role of social position and the urbanity gradient (the distance between the residence of voters and major urban centres) in explaining electoral behaviour, helping to refine and spatialise the behaviour studied by electoral sociology at regional and local level. However, the approach developed in regional science on the analysis of electoral behaviour goes further.

First, it introduces the role of spatial interdependencies through the use of spatial econometric models (e.g., Lacombe et al., 2014; Sampson, 2019). While electoral geography is often content with carrying out typological analyses of areas (Principal Component Analysis, followed by Hierarchical Ascending Classification), studies in regional science make it possible to introduce the idea that a change in an explanatory variable in one region can affect the vote in a neighbouring region. More generally, the introduction of spatial effects into electoral research makes it possible to show that the local public policies implemented in an area can have an impact not only on voting behaviour in the area in question, but also on neighbouring areas.

Second, there is a body of literature in regional science on path dependence that provides additional explanations for voting behaviour (Martin and Sunley, 2006; Martin, 2010). However, our results show that in municipalities characterised by a form of lock-in in terms of marginality, and where there has been a decline in public services, abstentionism is higher. It is important to take these path dependence effects into account because opportunities for individuals to be socially or spatially mobile determine voting behaviour (Lee et al., 2018; McCann, 2020; Tubadji et al., 2021). In our study, people that 


\section{Paper accepted in International Regional Science Review}

abstained felt disengaged because they knew that voting would not change their destiny, namely, being stuck in a neglected area.

Third, the strength of regional science is that it considers economic, demographic and geographical aspects simultaneously. From this point of view, it studies contextual effects in greater depth, and recent publications in regional science on the anti-establishment vote illustrate this well. The issue of regional concentration effects and interregional inequalities is also central in regional science (Rey, 2018; Franklin and van Leeuwen, 2018). The accumulation of wealth in certain areas and the neglect of others is a key factor in explaining why people vote for populist parties in some areas or else abstain. The lack of opportunities for people living in these neglected areas coupled with territorial inequalities linked to socio-economic changes such as de-industrialisation have led to discontent that is reflected in the ballot box. Recent publications in regional science also show the complex nature of the analysis. For example, in the context of Brexit, regions in the south of England - considered wealthier - voted to leave the EU (Los et al., 2017; Lee et al. 2018), even though electoral geography and sociology theories predicted the opposite. Dijstra et al. (2020) reached similar conclusions in the context of Euroscepticism in Europe. Our findings also show that, in the second round of voting, areas with a high share of managers were more likely to abstain as a result of their dissatisfaction with the political offer (Marine Le Pen versus Emmanuel Macron).

Fourth, regional science is particularly interested in the implications of the outcomes of public policy. In the context of our study and recent research on electoral behaviour, lack of employment opportunities has been shown to aggravate regional divides, and consequently resentment (Rodríguez-Pose, 2018). Yet research (such as Lobao et al., 2012) has also shown that local governments can significantly influence job creation or poverty. The results of our study suggest that territories neglected by public policies are more likely to engage in protest behaviour or despair by choosing not to vote.

\section{Conclusion}

Our study concludes by confirming that people who are socially and politically marginalized tend to follow a non-voting culture due to disenchantment as well as protestation. Abstention can also be found among people that are at the center of political life, but are living in neglected areas. By not voting, they 
aim to send an explicit protest message to political parties and the political system. In this case, abstention reflects a protest attitude. We also showed how abstention is a disengagement vote. People decide not to vote because they do not see themselves as being represented in the politics on offer. In the study, we found that municipalities with a large share of young adults are less politically engaged, either due to generational effects or because they are more susceptible to factors like unemployment. At the same time, municipalities with a large share of individuals with low levels of education and young people exhibit greater political passivity. Our study also shed light on the importance of spatial dependencies, as we found that the characteristics of municipal neighbors, both observed and unobserved, have a significant impact on abstention behavior, hence the need to take spatial areas into account.

Since we do not have individual data, it is difficult to separate the protest vote from the disengagement vote. Consequently, those that disengage may do so because they are protesting, while people in disadvantaged areas may be disillusioned or protesting. The use of variables describing the characteristics of municipalities, such as the percentage of workers, executives or university graduates, is therefore not intended to isolate individual behaviors, but rather to take these variables into account as markers of spatial configurations (Taylor and Johnston, 2014). The two hypotheses tested in our article are not contradictory, but can both be true. In this respect, the approach developed in regional science to highlight how specific territorial characteristics can explain one behavior rather than another is useful.

Our paper argues for the ecological and contextual analyses recently developed in regional science by examining the spatial dimension of the vote, and including the role of territorial characteristics that may influence voting. It would be interesting for future research to compare abstention with other types of protest votes - such as voting for extremist parties - in order to analyze the extent to which their determinants differ. Another research perspective could be to analyze abstention over time (e.g., several presidential elections) to identify which parameters are constant and which vary. Finally, our study focused on the Paris metropolis. It might be interesting to extend the analysis to other international conurbations from a comparative perspective in order to identify permanent features of the explanatory 


\section{Paper accepted in International Regional Science Review}

model. It could also be useful to conduct a comparative analysis of abstention in rural versus urban areas.

Our paper sought to highlight the existence of spatially structured inequalities in electoral participation. Previous research in regional science has highlighted how inter- and intra-regional inequalities were structured by and influenced local economic development (Beenstock \& Felsenstein, 2007; Artelaris and Petrakos, 2016; Rey, 2018). Taking these inequalities into account is crucial to our understanding of voting behaviours. Identification of these spatially structured inequalities allows the link between socio-spatial segregation and electoral participation to be observed. From this perspective, regional scientists are particularly well placed to show how socio-economic and territorial inequalities can explain electoral behavior. We believe it is necessary to study voting in cities most affected by marginalization and/or economic inequality in order to highlight the geography of political disengagement versus the geography of political contestation.

This paper assumes that heterogeneous electoral participation rates have territorial extensions, with the consequence that certain areas tend to remain on the margins of political life in the lead up to and during elections. Consequently, public policies should seek to match the needs of inhabitants with the quality of life offered. The current mismatch between the real needs of inhabitants and the supply of services to the population is liable to have a major impact on electoral results (a continual increase in protest votes, to the benefit of votes for extreme political parties and abstention) and the marginalization of part of society, particularly in large urban areas. 


\section{Bibliography}

1 Agnew, J. (1996). Mapping politics: how context counts in electoral geography. Political geography, 15(2), 129-146.

2 Anderson, C. J., \& Beramendi, P. (2012). Left parties, poor voters, and electoral participation in advanced industrial societies. Comparative Political Studies, 45(6), 714-746.

3 Anselin L., Bera A. K., Florax R., Yoon M. J.(1996). Simple diagnostic tests for spatial dependence, Regional science and urban economics 26.1, p. 77-104

4 Artelaris, P., \& Petrakos, G. (2016). Intraregional spatial inequalities and regional income level in the European Union: Beyond the inverted-U hypothesis. International Regional Science Review, 39(3), 291-317.

5 Arzheimer, K., Evans, J., \& Lewis-Beck, M. S. (Eds.). (2016). The Sage handbook of electoral behaviour. Sage.

6 Beenstock, M., \& Felsenstein, D. (2007). Mobility and mean reversion in the dynamics of regional inequality. International Regional Science Review, 30(4), 335-361.

7 Bon, F., \& Cheylan, J. P. (1988). La France qui vote. FeniXX.

8 Braconnier, C., \& Dormagen, J. Y. (2007). La démocratie de l'abstention (pp. 158-9). Paris: Gallimard.

9 Braconnier, C., \& Dormagen, J. Y. (2012). Logiques de mobilisation et inégalités sociales de participation électorale en France, 2002-2012. French Politics, Culture \& Society, 30(3), 20-44.

10 Burden, B. C. (2009). The dynamic effects of education on voter turnout. Electoral studies, 28(4), 540-549.

11 Burden, B.C., Wichowsky, A., (2014). Economic Discontent as a Mobilizer: Unemployment and Voter Turnout. The Journal of Politics, 76(4).

12 Bussi, M. (1998). Eléments de géographie électorale. Le Havre, Presses universitaires du Havre.

13 Busteed, M. A. (1975). Geography and voting behaviour. Oxford University Press.

14 Buton, F., Lemercier, C., \& Mariot, N. (2012). The household effect on electoral participation. A contextual analysis of voter signatures from a French polling station (1982-2007). Electoral Studies, $31(2), 434-447$.

15 Carpini, M. X. D., \& Keeter, S. (1996). What Americans know about politics and why it matters. Yale University Press.

16 Carreras, M., \& Castañeda-Angarita, N. (2019). Economic adversity and electoral participation of vulnerable socioeconomic groups. Electoral Studies, 57, 110-120.

17 Charney, I., \& Malkinson, D. (2015). Between electoral and urban geography: Voting patterns and socio-spatial dynamics in Tel Aviv. Applied Geography, 58, 1-6.

18 Cox, K. R. (1968). Suburbia and Voting Behavior in the London Metropolitan Area 1. Annals of the Association of American Geographers, 58(1), 111-127.

19 Cox, K. R. (1969). The voting decision in spatial context. Progress in Human Geography 1(2), pp. 81-117. 
20 Cox, K. R., Low, M., \& Robinson, J. (Eds.). (2007). The SAGE handbook of political geography. Sage.

21 De Maesschalck, F. (2011). The politicisation of suburbanisation in Belgium: towards an urbansuburban divide. Urban Studies, 48(4), 699-717.

22 Dijkstra, L., Poelman, H., \& Rodríguez-Pose, A. (2020). The geography of EU discontent. Regional Studies, 54(6), 737-753.

23 Duranton, G., Henderson, V., \& Strange, W. (Eds.). (2015). Handbook of regional and urban economics. Elsevier.

24 Enos, R. D. (2016). What the demolition of public housing teaches us about the impact of racial threat on political behavior. American Journal of Political Science, 60(1), 123-142.

25 Esser, F., \& De Vreese, C. H. (2007). Comparing young voters' political engagement in the United States and Europe. American behavioral scientist, 50(9), 1195-1213.

26 Fisher, J., Fieldhouse, E., Franklin, M. N., Gibson, R., Cantijoch, M., \& Wlezien, C. (Eds.). (2017). The Routledge handbook of elections, voting behavior and public opinion. Routledge.

27 Fleming, M. (2006). The 2005 Parliamentary and Presidential Elections in Poland: The Geography of Abstention. Debatte: Journal of Contemporary Central and Eastern Europe, 14(2), 91118.

28 Ford, R., \& Goodwin, M. J. (2014). Revolt on the right: Explaining support for the radical right in Britain. Routledge.

29 Franklin, R. S., \& van Leeuwen, E. S. (2018). For whom the bells toll: Alonso and a regional science of decline. International regional science review, 41(2), 134-151.

30 Gaxie, D. (1989). Explication du vote: un bilan des études électorales en France. Presses de Sciences Po.

31 Gianturco Gulisano, A., \& Darwich, I. (2015). Abstentionism, Blank Vote and Invalid Ballot Papers: Evidences from Brazil and EU. Available at SSRN 2548161.

32 Gimpel, J. G., Dyck, J. J., \& Shaw, D. R. (2004). Registrants, voters, and turnout variability across neighborhoods. Political Behavior, 26(4), 343-375.

33 Gomez, B. T., Hansford, T. G., \& Krause, G. A. (2007). The Republicans should pray for rain: Weather, turnout, and voting in US presidential elections. The Journal of Politics, 69(3), 649-663.

34 Goodchild, M. F., Anselin, L., Appelbaum, R. P., \& Harthorn, B. H. (2000). Toward spatially integrated social science. International Regional Science Review, 23(2), 139-159.

35 Gordon, I. R. (2018). In what sense left behind by globalisation? Looking for a less reductionist geography of the populist surge in Europe. Cambridge Journal of Regions, Economy and Society, 11(1), 95-113.

36 Guilluy, C. (2019). Fractures françaises. Flammarion.

37 Hansford, T. G., \& Gomez, B. T. (2010). Estimating the electoral effects of voter turnout. American political Science review, 268-288.

38 Heath, O. (2018). Policy alienation, social alienation and working-class abstention in Britain, 1964-2010. British Journal of Political Science, 48(4), 1053-1073. 
39 Hendrickson, C., Muro, M., \& Galston, W. A. (2018). Countering the geography of discontent: Strategies for left-behind places. Report, Brookings Institution, Washington, DC.

40 Hochschild, A. R. (2018). Strangers in their own land: Anger and mourning on the American right. The New Press.

41 Hughes, S., \& Guerrero, M. A. (2009). The disenchanted voter: Emotional attachment, social stratification, and mediated politics in Mexico's 2006 presidential election. The International Journal of Press/Politics, 14(3), 353-375.

42 Hunt, D. B. (2018). Public Housing in Urban America. In Pliley, J. Oxford Research Encyclopedia of American History. Oxford University Press.

43 Johnston, R., Jones, K., Sarker, R., Propper, C., Burgess, S. and Bolster, A. (2004). Party support and the neighborhood effect: spatial polarization of the British electorate, 1991-2001. Political Geography 23, pp. 367-402.

44 Klatzmann J. (1957). Comportement électoral et classe sociale. In Duverger, M., Goguel, F., Touchard, J. (dir.). Les Élections du 2 janvier 1956, Paris: Presses de la FNSP, p. 254-285.

45 Kostelka, F. (2017). Does democratic consolidation lead to a decline in voter turnout? Global evidence since 1939. American Political Science Review, 111(4), 653-667.

46 Kselman, D., \& Niou, E. (2011). Protest voting in plurality elections: a theory of voter signaling. Public Choice, 148(3-4), 395-418.

47 Lacombe, D. J., Holloway, G. J., \& Shaughnessy, T. M. (2014). Bayesian estimation of the spatial Durbin error model with an application to voter turnout in the 2004 presidential election. International Regional Science Review, 37(3), 298-327.

48 Lahtinen, H., Mattila, M., Wass, H., \& Martikainen, P. (2017). Explaining social class inequality in voter turnout: The contribution of income and health. Scandinavian Political Studies, 40(4), 388-410.

49 Lancelot, A. (1968). L'abstentionnisme électoral en France, Paris, Voir, 216 p.

50 Lazarsfeld, P. F., Berelson, B., \& McPhee, W. N. (1966). Voting: a study of opinion formation in a presidential campaign. University of Chicago Press.

51 Lazarsfeld, P., Berelson, B., \& McPhee, W. (1954). Voting. Chicago: University of Chicago.

52 Le Roux, G., Vallée, J., \& Commenges, H. (2017). Social segregation around the clock in the Paris region (France). Journal of Transport Geography, 59, 134-145.

53 Lee, N., Morris, K., \& Kemeny, T. (2018). Immobility and the Brexit vote. Cambridge Journal of Regions, Economy and Society, 11(1), 143-163.

54 Legnante, G., \& Segatti, P. (2009). Intermittent abstentionism and multi-level mobilisation in Italy. Modern Italy, 14(2), 167-181.

55 Leighley, J. E., \& Nagler, J. (2013). Who votes now?: Demographics, issues, inequality, and turnout in the United States. Princeton University Press.

56 Lévy, J. (2003). Quelle France voulons-nous habiter? Vote, urbanité et aménagement du territoire. Working paper, 121-139.

57 Lobao, L., Jeanty, P. W., Partridge, M., \& Kraybill, D. (2012). Poverty and place across the United States: Do county governments matter to the distribution of economic disparities?. International Regional Science Review, 35(2), 158-187. 
58 Los, B., McCann, P., Springford, J., \& Thissen, M. (2017). The mismatch between local voting and the local economic consequences of Brexit. Regional studies, 51(5), 786-799.

59 Martin, R. (2010). Roepke lecture in economic geography-rethinking regional path dependence: beyond lock-in to evolution. Economic geography, 86(1), 1-27.

60 Martin, R., \& Sunley, P. (2006). Path dependence and regional economic evolution. Journal of economic geography, 6(4), 395-437.

61 McAvay, H., \& Verdugo, G. (2021). Income Inequality and Segregation in the Paris Metro Area (1990-2015). In van Ham, M. Urban Socio-Economic Segregation and Income Inequality: A Global Perspective. Springer Nature.

62 McCann, P. (2020). Perceptions of regional inequality and the geography of discontent: Insights from the UK. Regional Studies, 54(2), 256-267.

63 Mur, J., Angulo, A. M., \& López, F. A. (2012). Looking for the Causes of Instability in Spatial Econometric Models: An Application to 2008 Spanish General Elections. International Regional Science Review, 35(3), 303-338.

64 Nijman, J., \& Wei, Y. D. (2020). Urban inequalities in the 21st century economy. Applied Geography, 117, 102188.

65 Pasek, J., Tahk, A., Lelkes, Y., Krosnick, J. A., Payne, B. K., Akhtar, O., \& Tompson, T. (2009). Determinants of turnout and candidate choice in the 2008 US presidential election: Illuminating the impact of racial prejudice and other considerations. Public Opinion Quarterly, 73(5), 943-994.

66 Peneff, J. (1981) Abstention ouvrière, participation bourgeoise aux élections de Nantes en 1977 et 1978, Le mouvement social, 115, pp. 3-25

67 Portos, M., Bosi, L., \& Zamponi, L. (2020). Life beyond the ballot box: the political participation and non-participation of electoral abstainers. European Societies, 22(2), 231-265.

68 Préteceille, E. (2009). La ségrégation ethno-raciale a-t-elle augmenté dans la métropole parisienne?. Revue française de sociologie, 50(3), 489-519.

69 Ranger, J. (1977). Droite et gauche dans les élections à Paris (1965-1977): le partage d'un territoire. Revue française de science politique, 789-819.

70 Rey, S. J. (2018). Bells in space: The spatial dynamics of US interpersonal and interregional income inequality. International Regional Science Review, 41(2), 152-182.

71 Rey, S. J., \& Le Gallo, J. (2009). Spatial analysis of economic convergence. In Patterson, K., \& Mills, T. C. (Eds.). Palgrave handbook of econometrics. Palgrave Macmillan. Palgrave handbook of econometrics, 1251-1290.

72 Riviere, J. (2008). Is there a Suburban Vote? Electoral Behaviours and Social Status in a Changing Rural Context. POLITIX, 21(83).

73 Riviere, J. (2014). Les divisions sociales des métropoles françaises et leurs effets électoraux. Métropolitiques, online review

74 Robinson, W.S. (1950). Ecological correlations and the behavior of individuals.American Sociological Review, 15:351-7.

75 Rodríguez-Pose, A. (2018). The revenge of the places that don't matter (and what to do about it). Cambridge journal of regions, economy and society, 11(1), 189-209. 
76 Rodríguez-Pose, A. (2020). The rise of populism and the revenge of the places that don't matter. LSE Public Policy Review, 1(1).

77 Roy, J., Perrella, A. M., \& Borden, J. (2015). Rural, suburban and urban voters: Dissecting residence based voter cleavages in provincial elections. Canadian Political Science Review, 9(1), 112127.

78 Sampson, R. J. (2019). Neighbourhood effects and beyond: Explaining the paradoxes of inequality in the changing American metropolis. Urban Studies, 56(1), 3-32.

79 Scala, D. J., \& Johnson, K. M. (2017). Political polarization along the rural-urban continuum? The geography of the presidential vote, 2000-2016. The ANNALS of the American Academy of Political and Social Science, 672(1), 162-184.

80 Soininen, M. \& Bäck, H. (1999). Electoral participation among immigrants in Sweden: integration, culture and participation », In Vertovec, S. (ed.). Migration and Social Cohesion, Cheltenham \& Northampton, Elgar Publishing, pp. 203-221.

81 Sonenshein, R. J., \& Drayse, M. H. (2006). Urban electoral coalitions in an age of immigration: Time and place in the 2001 and 2005 Los Angeles mayoral primaries. Political Geography, 25(5), 570595.

82 Spicer, J. S. (2018). Electoral systems, regional resentment and the surprising success of AngloAmerican populism. Cambridge Journal of Regions, Economy and Society, 11(1), 115-141.

83 Stakhovych, S., \& Bijmolt, T. H. (2009). Specification of spatial models: A simulation study on weights matrices. Papers in Regional Science, 88(2), 389-408.

84 Stanyer, J. (1975). On the Study of Urban Electoral Behaviour. In Essays on the Study of Urban Politics (pp. 25-51). Palgrave Macmillan, London.

85 Superti, C. (2014). Vanguard of the discontents: blank and null voting as sophisticated protest. Midwest Political Science Association.

86 Taylor, P. J., \& Johnston, R. (2014). Geography of elections. Routledge.

87 Tiberj, V. (2013). Values and the votes from Mitterrand to Hollande: The rise of the two-axis politics. Parliamentary Affairs, 66(1), 69-86.

88 Tubadji, A., Colwill, T., \& Webber, D. (2021). Voting with your feet or voting for Brexit: The tale of those stuck behind. Regional Science Policy \& Practice, 13(2), 247-277.

89 Ubarevičienè, R., Burneika, D., \& van Ham, M. (2015). Ethno-political effects of suburbanization in the Vilnius urban region: An analysis of voting behavior. Journal of Baltic Studies, 46(2), 217-242.

90 van Leeuwen, E. S., Halleck Vega, S., \& Hogenboom, V. (2020). Does population decline lead to a "populist voting mark-up"? A case study of the Netherlands. Regional Science Policy \& Practice.

91 Vassil, K., Solvak, M., \& Ehin, P. (2016). More choice, higher turnout? The impact of consideration set size and homogeneity on political participation. Journal of Elections, Public Opinion and Parties, 26(1), 78-95.

92 Walks, R. A. (2005). City-suburban electoral polarization in Great Britain, 1950-2001. Transactions of the Institute of British Geographers, 30(4), 500-517.

93 Weaver, R. (2014). Contextual influences on political behavior in cities: Toward urban electoral geography. Geography Compass, 8(12), 874-891. 
$94 \mathrm{Xu}, \mathrm{Y} .$, \& Luo, D. (2021). Is China's public housing programme destined to fail? Evidence from the city of Changsha. Population, Space and Place, 27(1), e2375.

95 Yandri, P. (2017). The political geography of voters and political participation: evidence from local election in suburban Indonesia. The Indonesian Journal of Geography, 49(1), 57. 